\section{TURNING POINT}

Speaking out

of US President Donald Trump,

Joel Clement, former director of the Office

窝 of Policy Analysis at the US Department of the Interior, wrote an opinion piece in The Washington Post. In it, he argued that his reassignment to an accounting post was intended to silence his work on climatechange adaptation among Alaska Native communities. Since leaving the agency last October, he has continued to advocate for the use of science when making policy decisions.

You were hired under President Obama? Yes. I came to Interior in 2011, after 8 years at a non-profit foundation in Seattle, Washington, that works on science-based conservation solutions. At Interior, which manages 75\% of federal public lands, I built links with scientists, other federal agencies and political leaders. The most successful arena for doing that was climate adaptation and resilience - areas that Interior must address. No one was looking at the Arctic, where $60 \%$ of Interior-managed land is located, so I knew we needed to establish a climate-resilience plan for the region. In 2016, I co-chaired the Arctic Resilience Assessment (see go.nature. com/2gwfqrt) with Johan Rockström, executive director of the Stockholm Resilience Centre, which authored a plan for addressing 당 crual climate concerns that could reshape the Arctic, such as shifts in ice cover, extreme weather events and a collapse in fisheries.

Can you describe the Trump transition? Nothing could have prepared me. I assured international colleagues that Arctic resilience would remain a priority. I was so wrong.

What prompted the opinion piece?

I'd worked on climate policy for seven years, and last July I was assigned to the Office of Natural Resources Revenue, which collects royalty cheques from oil and gas companies. I had been speaking out about the dangers of climate change for Alaska Native communities. In this new post, I could no longer do that. After speaking to a lawyer, it was clear that I had a legitimate whistleblower case.

\section{Why did you resign?}

After the opinion piece ran (see go.nature. com/2gwhdwh), I took a few days off. When I returned, I was floored by the support I got from Interior career folks, who showed me a stack of fan mail. I had no communications from high-level Interior staff. Once you are an

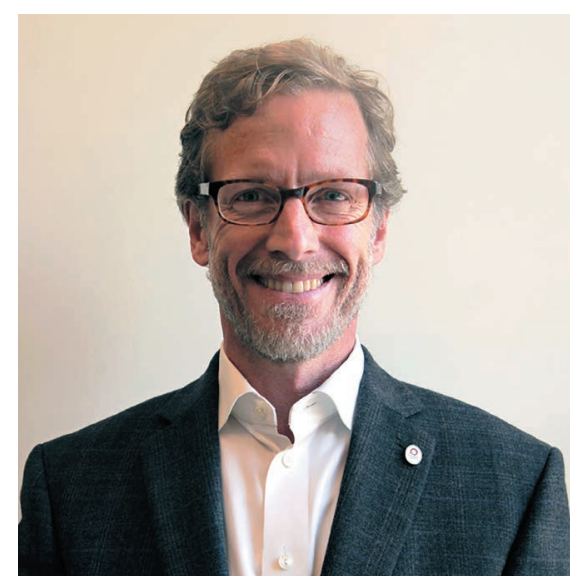

official whistleblower, you have protections. When I realized that I could have more of an impact on this administration outside the agency, I wanted to go out with a clear message for Interior Secretary Ryan Zinke. On 6 October, I published my resignation letter, which called out poor leadership in the agency and the dangers of ignoring scientific expertise on climate change. It went viral.

\section{Have other agency scientists contacted you} for whistleblowing advice?

Dozens.

What did you learn from your experience? If you think you have a valid whistleblower complaint, find a lawyer who is well versed in employment law, and determine whether it is valid. And scientific-integrity policies exist at every agency. I've heard of scientists being told they can't present their work at conferences, which is a violation of those policies.

\section{What have you done since October?}

I've never been busier. I have been talking to the media to hold this administration accountable. I've turned down job offers to get this message across.

Would you work for a federal agency again? I would. I feel strongly about the role that a scientist can have in the federal government. At Interior alone, there are 70,000 employees. In the next five years, nearly half will be eligible for retirement. We could have a real generational change that brings new ideas and approaches into federal government. We'll need good, smart folks to get it right..

\section{INTERVIEW BY VIRGINIA GEWIN}

This interview has been edited for length and clarity.

\section{COMPETITION}

\section{Science on camera}

Do you like taking pictures of your work in the field - tracking polar bears, for example, scaling glaciers, examining fossils? Or of what you see daily in the laboratory, perhaps under a microscope or in a Petri dish?

If so, why not enter our second annual \#ScientistAtWork photo competition? Here's how it works. Just send us your favourite picture (and any questions) to photocompetition@nature.com, or upload your image to Twitter or Instagram with the tag \#ScientistAtWork. All entries (no more than one per person) must reach us by the end of March. The winning images will be chosen by an independent panel of Nature editors and art staff, who will be looking for pictures that tell an interesting story and reflect the variety of work that scientists do.

We will publish the five winning entries in the 26 April issue of Nature. As well as being highlighted in these pages, winners will receive a year's personal subscription to Nature, in print and online. (And eternal glory, of course.)

The stories that came with last years' images were as compelling as the photos themselves. After taking her winning entry, Kseniia Ashastina found herself staring down a gun barrel, having raised the suspicions of two locals who'd been digging up and selling the tusks of woolly mammoths (you can read how that turned out at go.nature.com/2gbob7w).

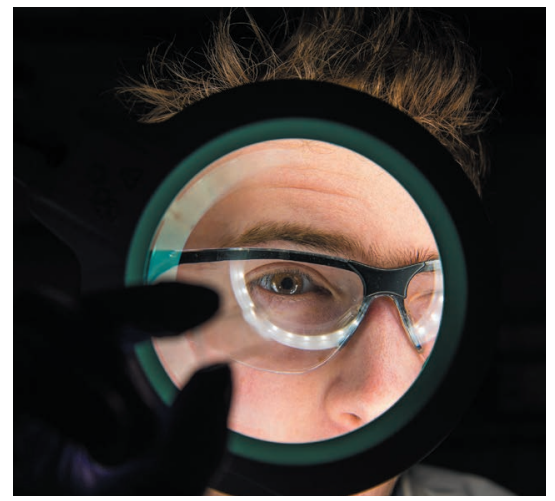

Microfluidic chip up close (a 2017 submission).

We're looking for images that highlight the working life of scientists in a dynamic, creative way. Heavily edited images will not be considered (see the terms and conditions on our dedicated blog at go.nature.com/scientistatwork), and photographs must be of high-enough quality (300 dpi at 220 millimetres wide) to appear in print.

Good luck, and we look forward to seeing your submissions. 